\title{
МОДЕЛЮВАННЯ ПРОЦЕСУ ВИХОВАННЯ ДУХОВНО-МОРАЛЬНИХ ЦІННОСТЕЙ У СТУДЕНТІВ ГУМАНІТАРНИХ СПЕЦІАЛЬНОСТЕЙ ЗАСОБАМИ ХУДОЖНЬОЇ ЛІТЕРАТУРИ
}

2. Bespalko, V. P. (1995). Pedagogika i progressivnyie tehnologii obucheniya [Pedagogy and progressive technologies of teaching]. Moscow.: IRPO MO, 336 p. [in Russian].

3. Bulah, I. E. (2006). StvoryuEmo yakisniy test [Creating a qualitative test]. Kyiv: Mayster-klas, 160 p. [in Ukrainian].

4. Efremova, N. F. (2007). Testovyiy kontrol v obrazovanii [Test control in education]. Moscow: Logos, 368 p. [in Russian].

5. Mayorova, N. L. (2000). Testirovanie kak pedagogicheskoe sredstvo izmereniya uspeshnosti obucheniya [Testing as a pedagogical means of the learning success measuring]. Candidate's thesis. Yaroslavl, 216 p. [in Russian].

6. Turikova, E. A. (2016). Lingvodidakticheskoe testirovanie kak sredstvo obuchayuschego kontrolya urovnya sformirovannosti obscheuchebnyih i professionalnyih kompetentsiy studentov-nefilologov [Linguodidactical testing as a means of training control for the general educational and professional competences formation level of non-philological students]. Candidate's thesis. Moscow, $200 \mathrm{p}$. [in Russian].

7. Fetisov, V. S. (2011). Kompyuterni tehnologiyi v testuvanni [Computer technology in testing]. Nizhin: Lisenko M.M. Publ., 140 p. [in Ukrainian].

8. Chelyishkova, M. B. (2002). Teoriya i praktika konstruirovaniya pedagogicheskih testov [Theory and practice of developing pedagogical tests]. Moscow: Logos, 432 p. [in Russian].

9. Available at: http://www.softportal.com/software1131-unitest-system.html [in Russian].

Стаття надійшла до редакції 02.03.2018

УДК [378.015.31:17.022.1]:821

DOI:

Сергій Гуров, кандидат педагогічних наук, доиент кафедри англійської філологї̈ та методики викладання англійської мови Мелітопольського державного педагогічного університету імені Богдана Хмельницького

\section{МОДЕЛЮВАННЯПРОЦЕСУ ВИХОВАННЯДУХОВНО-МОРАЛЬНИХЦННОСТЕЙ УСТУДЕНТІВГУМАНТТАРНИХСПЕЦАЛЬНОСТЕЙЗАСОБАМИХУДОЖНЬОЇЛТТЕРАТУРИ}

У статті представлено теоретико-концептуальну модель виховання духовно-моральних ияінностей студентів гуманітарних спеціальностей засобами художньої літератури, проведено аналіз теоретичних працьв вітчизняних та зарубіжних науковців, який свідчить, щчо необхідність педагогічного моделювання зумовлена потребою в об' єднанні всіх знань про особистість, в якої необхідно виховати духовно-моральні иінності засобами художньої літератури. Ефективне виховання духовних і моральних иінностей студентів гуманітарних наук можливе за умови створення теоретично обгрунтованої та експериментально підтвердженої теоретико-кониептуальної моделі.

Ключові слова: духовно-моральні ияінності; студенти гуманітарних спеціальностей; теоретикоконцептуальна педагогічна модель.

תim. 6.

Serhiy Hurov, Ph.D.(Pedagogy), Associate Professor of the English Philology and Methods of Teaching English Department Melitopol Bohdan Khmelnytskiy State Pedagogical University

\section{MODELING THE PROCESS OF EDUCATION OF SPIRITUAL-MORAL VALUES AMONG STUDENTS OF HUMANITARIAN SPECIALTIES BY MEANS OF IMAGINATIVE LITERATURE}

The article deals with a theoretical and conceptual model of spiritual and moral values development of students of humanitarian specialties by means of imaginative literature, the analysis of theoretical works of scientists indicates that the necessity of pedagogical modeling is determined by the needs to combine all the knowledge about the personality. Thus, due to this model it becomes possible to educate spiritual and moral values by means of imaginative literature. The article also discovers effective education of the spiritual and moral values of students of humanities is possible provided that a theoretically grounded and experimentally verified theoretical-conceptual model is created. The article visualizes the theoretical and conceptual model of the process of raising the spiritual and moral values of students of humanitarian specialties by means of imaginative literature, as a descriptive analogue of the result, which reproduces the peculiarities of the pedagogical reality of higher educational institutions.

The components can be implemented due to a certain order in the technological process components of the model. Since the upbringing of spiritual and moral values is being investigated in the context of vocational training, the proposed model represents the integration of all the above components. At the same time, in this 


\section{МОДЕЛЮВАННЯ ПРОЦЕСУ ВИХОВАННЯ ДУХОВНО-МОРАЛЬНИХ ЦННОСТЕЙ У СТУДЕНТІВ ГУМАНІТАРНИХ СПЕЦІАЛЬНОСТЕЙ ЗАСОБАМИ ХУДОЖНЬОЇ ЛІТЕРАТУРИ}

model it is shown that the achievement of a high level is compulsory and without all three components the practical work will be inferior. Technological-procedural components foresee the implementation of the educational process in four stages: diagnostics, analysis and self-analysis of the levels of education of spiritual and moral values of students.

Planning of educational work, the choice of educational programs (implemented through methods of modeling, forecasting, designing, selection of specific exercises); the organization and regulation of the education of the spiritual and moral values of the students of the humanities by the means of imaginative literature implemented through the introduction of an elective interactive special course. model.

Keywords: spiritual and moral values; students of humanities; theoretical and conceptual pedagogical

П остановка проблеми. Оволодіння системою знань і навичок під час отримання педагогічної освіти в університетах уможливлює вдосконалення інтелектуальних здібностей особистості в цілому. Проте перевага інтелектуального розвитку перед духовно-моральним формує особистість напівосвіченою та бездуховною. Наведемо слова Д. Менделєєва, який казав, що знання без виховання $\epsilon$ мечем у руках божевільного. Саме від виховання молоді, яка завжди знаходиться в центрі соціальних змін і є одним 3 головних ресурсів суспільства залежить доля та суспільнонаціональне бугтя нашої країни. Освіту неможна розглядати без урахування прояву єдності навчання і виховання. Головним спрямуванням системи сучасної вітчизняної освіти має стати підготовка і виховання не тільки кваліфікованого спеціаліста-інтелектуала, який відповідає переліку компетентностей, зазначених в певних освітніх програмах, а й особистості духовної.

Аналіз досліджень та публікацій. У наукових розвідках багатьох учених знайшли відображення проблеми моделювання діяльності в навчальному процесі. Так, ми знаходимо фундаментальні наукові праці в галузі моделювання педагогічних, соціальних, виховних, аксіологічних систем у таких учених, як А. Агафонов, О. Анісимов, В. Григоренко, Б. Коротяєв, Г. Костюк, В. Міхеєв, Л. Сохань, В. Тюхтін, О. Федорова. В зазначених роботах у педагогічній літературі увага вчених зосереджена на визначенні сутності та структурних компонентах процесу моделювання.

Мета статті. Подання теоретикоконцептуальної моделі виховання духовноморальних цінностей студентів гуманітарних спеціальностей засобами художньої літератури.

Виклад основного матеріалу. Аналіз процесу виховання духовно-моральних цінностей, визначення i обгрунтування ціннісногермевтичного підходу як загальнонаукової основи і теоретико-методологічної стратегії нашого дослідження дають нам підстави для проектування теоретико-концептуальної моделі виховання духовно-моральних цінностей у студентів гуманітарних спеціальностей засобами художньої літератури. Необхідність педагогічного моделювання зумовлена потребою в об'єднанні всіх знань про особистість, в якої необхідно виховати духовно-моральні цінності засобами художньої літератури.

На сьогодні існуе чимало визначень поняття “педагогічна модель", які відображають певний аспект цього терміну: за визначенням В. Краєвського педагогічна модель $€$ переходом від відображення педагогічної діяльності до ії перетворення [4]. У В. Докучаєвої педагогічна модель пояснюється як синкретичний процес або описи в проектуванні [3]; О. Дахін схарактеризовує це поняття як концептуальний підхід до вирішення педагогічних завдань [2]. Нам імпонує визначення надане Т. Ващик, де педагогічна модель пояснюється як ідея про здійснення цілеспрямованого розвитку педагогічного об'єкта [1].

Моделювання як метод дослідницької діяльності забезпечує можливість розбудови теоретичної конструкції процесу виховання духовно-моральних цінностей у студентів гуманітарних спеціальностей, у якій втілений спосіб розуміння та пояснення сутності й природи досліджуваного об'єкта [5,43]. Такий спосіб моделювання є прикладом абстрактно-образного моделювання, що допомагає візуалізувати абстрактне поняття,зрозуміти причиннонаслідкові зв'язки досліджуваного процесу, не втратити цілісного уявлення про досліджуваний об'єкт, а також віднайти нову інформацію про цей об'єкт. Представлений у моделі аналіз і синтез процесу виховання духовно-моральних цінностей у студентів гуманітарних спеціальностей, що відтворюється, дає можливість моделювати педагогічний процес, у якому, як правило, виражається власне бачення характеристик досліджуваного об'єкта [6].

В проектованій нами моделі, яку ми створюємо у дослідженні ми враховуємо такі функції: власне моделювання як спосіб відображення та перетворення об'єкта, який ще не існує в реальності; гносеологічного інструменту пізнання, інноваційності, прогнозування і визначення стратегії виховання духовноморальних цінностей у студентів гуманітарних 
МОДЕЛЮВАННЯ ПРОЦЕСУ ВИХОВАННЯ ДУХОВНО-МОРАЛЬНИХ ЦІННОСТЕЙ У СТУДЕНТІВ ГУМАНІТАРНИХ СПЕЦАЛЬНОСТЕЙ ЗАСОБАМИ ХУДОЖНЬОӤ ЛІТЕРАТУРИ

спеціальностей засобами художньої літератури; оперування з об'єктами, щодо яких знання не представлено в певному обсязі і реалізації у практичних умовах освітньо-виховного середовища вищих навчальних закладів.

Таким об'єктом у нашому дослідженні виступає процес виховання духовно-моральних цінностей студентів гуманітарних спеціальностей засобами художньої літератури.

Отже, термін “модель” у нашому дослідженні розуміється нами як цілеспрямований процес створення моделі об'єкту-аналогу, яка відображає структурні, ієрархічні та функціональні властивості системи формування цього аксіологічного феномена у майбутніх фахівців.

Моделювання процесу виховання духовноморальних цінностей студентів гуманітарних спеціальностей засобами художньої літератури $\epsilon$ творчим процесом, який вимагає постановки мети, розробки відповідних поточних i перспективних завдань виховної діяльності, що включають такі компоненти: опис проблем духовно-морального характеру, попередньої діагностики сформованості духовно-моральних цінностей студентів гуманітарних спеціальностей, відображення властивостей, динаміки i психолого-педагогічних закономірностей та умов виховання духовно-моральних цінностей студентів гуманітарних спеціальностей, що становлять педагогічну систему 3 певною структурою (цілісністю), ієрархічністю i функціональністю.

Наступним етапом моделювання процесу виховання духовно-моральних цінностей студентів гуманітарних спеціальностей засобами художньої літератури вважаємо виокремлення суттєвих чинників, розробку алгоритму, вибір наукового, методичного забезпечення, моніторинг стану виховної роботи. На останньому етапі відбувається верифікація моделі, тобто вихідна діагностика, що виражається в оцінці результативності процесу виховання духовноморальних цінностей студентів гуманітарних спеціальностей засобами художньої літератури. Оцінка результативності духовно-морального виховання відбувається на основі використання системи об'єктивних критеріїв, яка включає цілеспрямованість виховного процесу і його системний характер; наукову обгрунтованість методів і використання сучасних технологій виховного впливу. На останньому етапі моделювання такою відбувається апробація моделі та узгодження іï на всіх рівнях управління у вищому навчальному закладі. Аналіз результатів виховної роботи (якісних і кількісних) дає можливість узагальнити моделювання процесу виховання духовно-моральних цінностей, провести експертизу щодо відповідності моделі до придатності у професійній підготовці майбугніх фахівців гуманітарних спеціальностей, доповнити або змінити елементи моделі тощо.

Таким чином, ми візуалізуємо теоретикоконцептуальну модель процесу виховання духовно-моральних цінностей студентів гуманітарних спеціальностей засобами художньої літератури як описовий аналог результату, що відтворює особливості педагогічної реальності BH3.

Концептуально-теоретична модель складається 3 таких компонентів: иіле-мотиваційного, теоретичного, технологічно-процесуального, змістовного, результативного.

В ціле-мотиваційному компоненті представлено мету процесу виховання духовноморальних цінностей, яка полягає у досягненні високого рівня вихованості духовно-моральних цінностей у студентів гуманітарних спеціальностей, що узгоджується на всіх рівнях управління вищого навчального закладу і реалізується за допомогою таких завдань: забезпечення інтересу до процесу виховання духовно-моральних цінностей; формування позитивної мотивації до підвищення рівня духовно-моральних цінностей засобами художньої літератури; формування позитивних духовноморальних якостей і викорінення негативних якостей; розширення інформаційного фондузнань про сутність та структуру духовно-моральних цінностей особистості, навчання вмінню рефлексії духовно-морального досвіду та його актуалізації як захисного механізму особистості, формування духовно-морального мислення; розвиток духовноморальних почуттів, навичок духовно-моральної поведінки, проектування власної поведінкової програми.

Під час виконання зазначених завдань дотримуються певного алгоритму, оскільки планомірне їх виконання забезпечує реалізацію мети виховання духовно-моральних цінностей студентів гуманітарних спеціальностей, яка полягає у підготовці майбутніх фахівців, здатних здійснювати духовно-моральний вибір і приймати рішення на основі сформованих внутрішніх критеріїв; готових до самовдосконаленням духовно-моральних рис; здатних виявляти почуття глибокого сердечного ставлення до оточення

До теоретичного компоненту належать: методологічні підходи, закономірності, принципи, педагогічні умови, реалізація яких сприятиме ефективному здійсненню процесу виховання 


\section{МОДЕЛЮВАННЯ ПРОЦЕСУ ВИХОВАННЯ ДУХОВНО-МОРАЛЬНИХ ЦІННОСТЕЙ У СТУДЕНТІВ ГУМАНІТАРНИХ СПЕЦІАЛЬНОСТЕЙ ЗАСОБАМИ ХУДОЖНЬОЇ ЛІТЕРАТУРИ}

духовно-моральних цінностей студентів гуманітарних спеціальностей. Ми розглянули зміст методологічних підходів у третьому розділі нашого дослідження, де дійшли висновку, що інтеграція ціннісного та герменевтичного методологічних підходів як комплементарних один одному, є новою теоретико-методологічною стратегією, метапринципом виховання духовноморальних цінностей студентів засобами художньої літератури, здатним змінити стратегію духовно-морального виховання у вищому навчальному закладі.

На основі методологічних підходів визначено відповідні принципи організації процесу виховання духовно-моральних цінностей студентів гуманітарних спеціальностей засобами художньої літератури, які дають можливість розглянути окреслену проблему в комплексі, детальніше уявити сутність, специфіку, цілісність досліджуваного явища, виявити умови реалізації завдань дослідження.

Аксіологічний принцип. Цінності визначають основний зміст духовно-морального розвитку та виховання особистості студента. Будь-який зміст навчання, спілкування, діяльності може стати змістом виховання, якщо він віднесений до певної цінності. Педагогічна організація духовноморального укладу того, хто навчається починається з визначення тієї системи цінностей, яка лежить в основі виховного процесу та розкривається в його змісті, цей процес триває все життя.

Принцип опори на фундаментальну основу духовно-моральних цінностей полягає у їх глибокому розумінні, що надає знання про їх прояви у різних виявах, що також спрямоване і на розвиток особистості майбутнього фахівця, на формування духовно-моральної свідомості тощо. У процесі професійної підготовки студентам важливо усвідомити роль і значення духовноморальних цінностей у певній хронології під час розкриття культурних, соціальних, економічних, політичних і релігійних подій ужитті українського народу, щоби зрозуміти, яким чином впливали i впливають закладені цінності на життя і творчість людей.

Принцип співтворчості викладача і студента у розвитку вмінь генерувати та розробляти технології та методики самовиховання і виховання дітей та учнівської молоді реалізується через організацію проблемно-діалогічного характеру виховної дії, що спрямована на взаємозбагачення науково-педагогічних працівників і студентів, підтримання суб'єкт-суб'єктних взаємин між учасниками виховного процесу. Основна увага в такому плані завжди прикута до партнера, його емоційного та психологічного стану під час генерації нових ідей, критичного відбору форм, методів виховання тощо.

Принцип орієнтації на результат у вихованні духовно-моральних цінностей майбутніх фахівців передбачає повернення уваги учасників процесу виховання на досягнення певного рівня сформованості духовно-моральних цінностей за допомогою позитивної мотивації, на формування сукупності спеціальних знань і умінь, готовності майбутніх фахівців до самовиховання i самовдосконалення

Принцип центрації виховання духовноморальних цінностей на інтерперсональному рівні реалізується через заглиблення майбутнім фахівцем у внутрішній особистісний вимір, вміння здійснювати рефлексію власного досвіду. Даний принцип реалізується також через самооцінку виховних результатів, самостійного відбору психолого-педагогічного матеріалу для виховання, розробки нових вправ для саморегуляції тощо. У цьому контексті студенти мають самостійно сприяти поліпшенню виховних програм, намагатися розуміти протилежні та полярні позиції, зміцнювати міжособистісні стосунки на різних рівнях, бути здатними на моральний вчинок який є основною мірою духовного розвитку особистості.

Відзначимо, що розглянуті принципи у навчально-виховному процесі мають виступати у взаємодії один 3 одним і функціонувати як цілісна система, будь-який з означених принципів набуває свого сутнісного значення лише у зв'язку 3 іншими. Ці принципи проявляються одночасно на кожному етапі процесу виховання духовноморальних цінностей студентів гуманітарних спеціальностей засобами художньої літератури, доповнюючи і підсилюючи один одного. Без сукупності роботи принципів неможливе правильне визначення завдань, відбір змісту, вибір форм, методів і засобів найдоцільнішої діяльності у вихованні духовно-моральних цінностей.

Щодо педагогічних умов, які $є$ складовими теоретичного компоненту моделі виховання духовно-моральних цінностей студентів гуманітарних спеціальностей, то серед них ми визначаємо: створення аксіологічно спрямованого освітньо-виховного простору і залучення студентів у діяльність 3 засвоєння духовноморальних цінностей у ньому; опора на ціннісний потенціал художньої літератури як засобу виховання духовно-моральних цінностей; створення умов для комфортного спілкування, 
МОДЕЛЮВАННЯ ПРОЦЕСУ ВИХОВАННЯ ДУХОВНО-МОРАЛЬНИХ ЦІННОСТЕЙ У СТУДЕНТІВ ГУМАНІТАРНИХ СПЕЦАЛЬНОСТЕЙ ЗАСОБАМИ ХУДОЖНЬОӤ ЛІТЕРАТУРИ

взаємодії, співпраці і співтворчості в навчальновиховному-процесі; організація процесу виховання на основі розробленого інтерактивного курсу “Художня література як чинник становлення духовно-моральної особистості студента", в якому передбачено створення ситуацій для постійного діалогу як форми взаємодії між учасниками; системне впровадження у навчально-виховний процес ідеї гуманізму, досягнень національної та світової художньої літератури, на засадах яких формується світогляд особистості студента.

До технологічно-процесуального компонента моделі ми включили такі складники як: використання адекватної системи методів і засобів діагностики вихованості духовно-моральних цінностей особистості студента для своєчасного вимірювання ефективності цього процесу та етапи реалізації процесу виховання духовно-моральних цінностей студентів гуманітарних спеціальностей засобами художньої літератури.

Наведені вище компоненти можуть бути реалізовані за умов дотримання визначеного порядку в технологічно-процесуальних складових моделі. Оскільки виховання духовно-моральних цінностей досліджується в контексті професійної підготовки, то у запропонованій моделі представлено інтеграцію всіх окреслених складових. При цьому в даній моделі відображається, що досягнення високого рівня $\epsilon$ обов'язковим і без усіх трьох складових практична робота буде неповноцінною. Технологічнопроцесуальні складові, у свою чергу, передбачають реалізацію виховного процесу на чотирьох етапах: діагностика, аналіз та самоаналіз рівнів вихованості духовно-моральних цінностей студентів (реалізується через методи спостереження, тестування, експертні оцінки, самооцінки, психодіагностичні методики); планування виховної роботи, вибір виховних програм (реалізується через методи моделювання, прогнозування, конструювання, підбору специфічних вправ); організація та регулювання виховання духовно-моральних цінностей студентів гуманітарних спеціальностей засобами художньої літератури (реалізується через запровадження елективного інтерактивного спецкурсу, розробку стимулюючих матеріалів, використанням специфічних форм і методів: лекції, семінари, бесіди, дискусії, диспути, тренінги поведінки, консультації, ділові та рольові ігри, методичні практикуми, психологопедагогічні семінари, саморегуляцію, самоаналіз, рефлексію); моніторинг та оцінка результативності процесу виховання духовно-моральних цінностей студентів (реалізується через методи аналізу й обговорення результатів на різних рівнях та ін.).
Виховання духовно-моральних цінностей студентів гуманітарних спеціальностей засобами художньої літератури передбачає етапність цього процесу. Отже, схарактеризуємо їх: етап усвідомлення образу духовно-моральних цінностей, етап впровадження набутих знань про духовно-моральні цінності у власну поведінку, етап аналізу і рефлексії власної поведінки щодо відповідності духовно-моральним цінностям.

Перший еman забезпечує ознайомлення студентів з поняттям “духовно-моральні цінності”" та надає їм можливість осягнути потенціал художньої літератури для виховання власної системи духовно-моральних цінностей на ㄲï основі. На цьому етапі відбувається усвідомлення принципових понять про добро і зло, що дає студентам можливість вибору дії, вчинку. Результат такої роботи - формування духовноморальної свідомості, у якій відображаються щирі духовно-моральні почуття, що висвітлюються через духовно-моральну діяльність, ставлення до себе й оточення. Процес ознайомлення студентів з потенціалом художньої літератури для виховання духовно-моральних цінностей може бути представлений як процес орієнтації особистості на цінності представлені в національній та світовій літературах. Орієнтація в цьому випадку передбачає наявність емоційного стану впевненості у правильності обраного шляху на самовдосконалення. Така орієнтація спрямовує студента від задуму до результату: вірний вибір мети та засобів іiї досягнення, оцінку власної дії в зіставленні вчинку із загальною спрямованістю, планами та життєвими цінностями. Таким чином, набутий студентом рівень знань поступово стає необхідною базою для постійного пошуку, розвитку, удосконалення і поглиблення наявних уявлень. Саме тому таку орієнтацію можна визначити як процес формування духовноморального стриженя, пошук свого місця і призначення у житті. Результатом і продуктом першого етапує сформована позитивна настанова на зміни власної поведінки відповідно до системи духовно-моральних цінностей.

Другий eman - етап впровадження набутих знань про духовно-моральні цінності у власну поведінку-це ціннісно-смислове визначення себе щодо цінностей виражених в літературі. Воно виражається у прагненні та бажанні студента чинити відповідно до системи духовно-моральних цінностей. Цей етап характеризується пристосуванням духовно-моральної свідомості студентів гуманітарних спеціальностей до конкретних умов існування. Захисний духовноморальний фільтр спрацьовує, коли пережиті 


\section{МОДЕЛЮВАННЯ ПРОЦЕСУ ВИХОВАННЯ ДУХОВНО-МОРАЛЬНИХ ЦНННОСТЕЙ У СТУДЕНТІВ ГУМАНІТАРНИХ СПЕЦІАЛЬНОСТЕЙ ЗАСОБАМИ ХУДОЖНЬОЇ ЛІТЕРАТУРИ}

почуття знаходять прояв через захисні реакції, спрямовуються на активне ствердження та підтримку справедливих дій інших.

Tретій етап процесу виховання духовноморальних иінностей студентів гуманітарних спеціальностей є етапом аналізу і рефлексії власної поведінки студентом щодо ії відповідності духовно-моральним цінностям оспіваними в літературі. Для цього етапу характерною $є$ неприйняття інформації студентом, яка несумісна 3 щирими духовно-моральними почуттями, сформованими за допомогою стимулюючих матеріалів. На цьому етапі студенти здатні аналізувати літературні твори щодо їхнього виховного потенціалу, також здійснювати самоконтроль власної поведінки відповідно до системи духовно-моральних цінностей.

Змістовий компонент моделі представлено методичним забезпеченням процесу виховання духовно-моральних цінностей студентів гуманітарних спеціальностей засобами художньої літератури. Відзначимо, що важливу роль в змістовному компоненті відіграють стимулюючі матеріали, обрані для виховання духовноморальних цінностей.

На наш погляд, стимулюючі матеріали, мають бути розробленими для студентів із урахуванням ï індивідуальних якостей i застосовані викладачами $з$ урахуванням діагностичних методик для роботи зі студентами, що дозволить ураховувати їхні особливості на різних рівнях. Розміщення стимулюючих матеріалів у навчальнометодичних комплексах гуманітарних спеціальностей стикається з питанням визначення пропорцій розміщення стимулюючих матеріалів у навчально-методичних комплексах і повинно розглядатися на основі психолого-педагогічних теорій. Відзначимо, що необхідно структурувати розроблений стимулюючий матеріал таким чином, щоб виконання розвивальних і пізнавальних завдань завжди поєднувалося 3 виховними. Рекомендована типова структура стимулюючого матеріалу для виховання духовно-моральних цінностей в навчально-методичному комплексі складається 3 таких елементів: найменування теми; мета та завдання вивчення теми; коротка характеристика розглянутих духовно-моральних якостей за темою; інформація 3 кожного питання теми (текст із малюнками, схемами, графіками, гіпертекст, мультимедіа тощо; висновки діагностики формування певних духовноморальних характеристик; питання і завдання для самостійної роботи (самовиховання саморегуляціі); список літератури й електронних ресурсів, що містять інформацію з теми.
Стимулюючі матеріали для виховання духовноморальних цінностей студентів гуманітарних спеціальностей повинні виконувати певні функції, а саме: професійна (відповідальність у виконанні професійних обов'язків), аналітична (вміння аналізувати запропонований матеріал відповідно наявності в ньому потенціалу для виховання духовно-моральних цінностей); творча (розвиває творчість і винахідливість студентів у прийнятті духовно-моральних рішень у нестандартних ситуаціях), перетворювальна (допомагає змінити ставлення до себе й оточення, виконання професійних і колективних доручень тощо); рефлексивна (допомагає здійснювати самоконтроль і інтроспекцію щодо вдосконалення власної поведінки відповідно до духовноморальних цінностей).

Варто відмітити, що під час впровадження стимулюючих матеріалів виникає необхідність спостереження за змінами у показниках сформованості духовно-моральних цінностей студентів та занесенням отриманої інформації в діагностичні карти, що дозволить не тільки ознайомитися з інформацією, але й відстежити якісні зміни, що відбуваються в свідомості майбутніх фахівців, побачити зміни в духовноморальній діяльності тощо. Для кількісного оцінювання ми залучаємо різні діагностичні методики і тести, написання есе, а також створення авторських проектів тощо. Це означає, що для моделі процесу виховання духовноморальних цінностей особливе значення мають функції контролю, координації, регулювання, основним інструментом якої є моніторинг виховної діяльності.

Результативним компонентом моделі виступає прогнозований результат: вихованість духовно-моральних цінностей, яка проявляється в розвитку особистісної духовно-моральної культури учасника взаємодії, і відповідає встановленим критеріям та рівням вихованості. Відповідно до теоретико-концептуальної моделі дослідження названо прояви, що відображають теоретичний рівень опису вихованості духовноморальних цінностей особистості. Розроблену модель реалізовано й експериментально перевірено у процесі впровадження спецкурсу виховання духовно-моральних цінностей студентів гуманітарних спеціальностей засобами художньої літератури. Цей спецкурс, входить до структури технологічно-процесуальних складових моделі виховання духовно-моральних цінностей студентів, він може входити як до варіативної частини професійно орієнтованого циклу за вибором ВНЗ (обсяг 3 кредити - відповідно 90 
годин), так і за вибором студента (орієнтовна кількість кредитів - 3, годин - 90). Він поділяється на лекційні, семінарські заняття та самостійну роботу.

Висновок. Узагальнюючи сказане, ми дійшли висновку, що ефективне виховання духовноморальних цінностей студентів гуманітарних спеціальностей можливе за умови створення теоретично обгрунтованої та експериментально перевіреної теоретико-концептуальної моделі. Подальшого розвитку на нашу думку є створення методичного забезпечення формування духовноморальних цінностей засобами художньої літератури на аудиторних заняттях та позакласній роботі.

\section{ЛITEPATУРA}

1. Ващик Т. І. Моделювання у навчальновиховному процесі вищої школи / Т.А.Ващик // Нові технології навчання. - К.: НМЦВО, 2005. Вип.41. - С.147-158

2. Дахин А. Н. Педагогическое моделирование как средство модернизации образования в открытом информационном сообществе [Електроний ресурс] / А. Н. Дахин. - Режим доступу: http://vio.uchim.info/Vio_21/cd site/articles/ art 1 6.htm. - Назва з екрану.

3. Докучаєва В. В. Проектування інноваційних педагогічних систем у сучасному освітньому просторі: монографія / В. В. Докучаєва. - Луганск: Альма-матер, 2005. - 304c.

4. Краевский В. В. Методология педагогического исследования: пособие для педагога-исследователя / В. В. Краевский. - Самара: Самарский ГПИ, 1994. - 165 с.

5. Педагогический словарь: учеб. пособие для студ. высш. учеб. заведений/ В. И. Загвязинский, А. Ф. Закирова, Т. А. Строкова и др.; под ред.
В. И. Загвязинского, А. Ф. Закировой. - Москва: Академия, 2008. -352 с.

6. Шумилин А. Т. Проблемы теории творчества / А. Т. Шумилин. - М.: Высш.шк., 1989. - 144 с.

\section{REFERENCES}

1. Vaschik, T.I. (2005). Modeljuvannja u navchalno-vyhovnomu procesi vyshhoi shkoly [Modeling in the educational process of higher education].New technologies of teaching. Kyiv: NMCVV, vol.41, pp. 147-158. [in Ukrainian].

2. Dakhin, A.N. Pedagogicheskoe modelirovanie kak sredstvo modernizacii obrazovanija v otkrytom informacionnom soobshhestve [Pedagogical modeling as a means of modernizing education in the open information community] [Electronic resource]. Access mode: http://vio.uchim.info/Vio_21/cd_site/articles/ art_1_6.htm. The name of the screen. [in Russian].

3. Dokuchaeva, V.V. (2005). Proektuvannja innovacijnyh pedagogichnyh system u suchasnomu osvitnomu prostori: monografija [Design of innovative pedagogical systems in the modern educational space: monograph]. Lugansk: Alma Mater, 304 p. [in Ukrainian].

4. Kraevsky, V.V. (1994). Metodologija pedagogicheskogo issledovanija: posobie dlja pedagoga-issledovatelja [Methodology of pedagogical research: manual for a teacher-researcher]. Samara: Samara GPI, 165p. [in Russian].

5. Zagvyazinsky, V.I., Zakirova, A.F. \& Strokov, T.A. (2008). Pedagogicheskij slovar: ucheb. posobie dlja stud. vyssh. ucheb. zavedenij [Pedagogical dictionary: manual for students of higher educational institutions and others]. Moscow: Academy, 352 p. [in Russian].

6. Shumilin, A.T. (1989). Problemy teorii tvorchestva [Problems of Creation Theory]. Moscow: Vyssh.shk., 144 p. [in Russian].

Стаття надійшла до редакції 05.03.2018

\section{ज58080ल2058080}

“Виробляй, розвивай свої здібності прачею, творчістю”.

Василь Сухомлинський видатний український педагог

“Моральність - основа всіх людських иінностей".

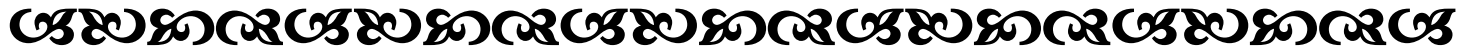

